\title{
STRATEGIC MANAGEMENT IN THE DEVELOPMENT OF A PSYCHOSOCIAL INTERVENTION PROJECT - EXPERIENCE IN A COMMUNITY OF THE PLAINS OF COLOMBIA
}

D. Vargas Chavez1, S. Martínez Gomez1. 1 Instituto Colombiano del Sistema Nervioso - Clinica Montserrat, Bogotá DC, Bogotá, Colombia.

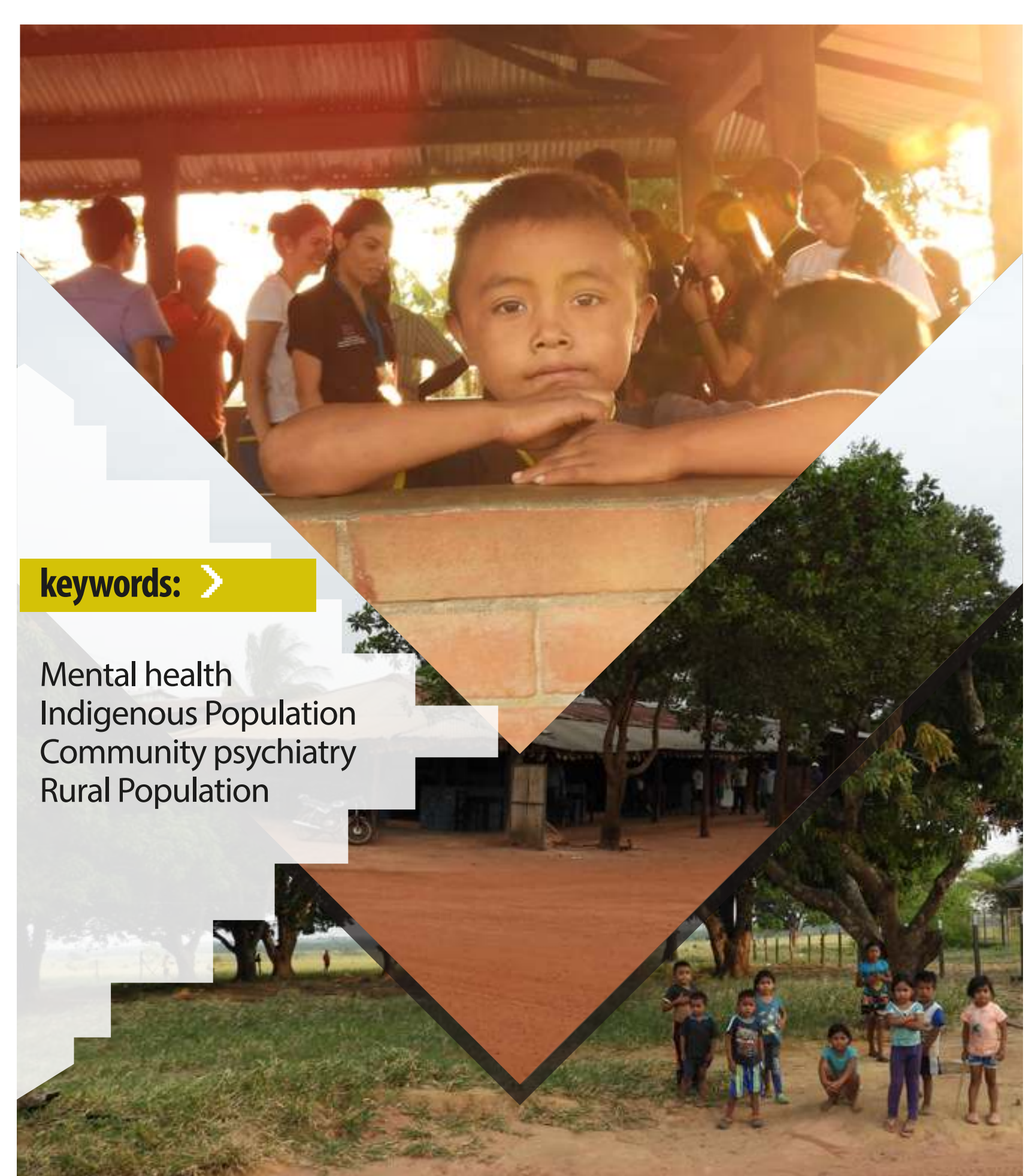

Introduction:

The description of the design is made and the implementation of an attention model in mental health for a three-ethnical population (indigenous - sikuani, Afrodescendent and mestiza) at the Eastern llanos of Colombia by a group of psychiatrist and residents of the Clinica Psiquiatrica Monserrat from Bogotá. Explain how from the strategic direction of a national leading institution in the assistance, teaching and research of mental health, a structured project is promoted within the program of corporate social responsibility, for service and research in a population victim of displacement and violence.

Activity that was carried out from the area of social responsibility of the institute. Focusing on the interest of supporting the formation and training of psychiatrists and residents in psychiatric with a global and differential approach of other psychiatrists from a community approach of the psychiatry with the purpose of conceiving this dynamic the knowledge of health and mental illness of this community.

During the participation a close up to the community was made by means of awareness and understanding activities in three groups: the community (indigenous and rural), the health staff of the hospital and the students attending the camp within the framework of topics such as management of suicidal behavior, community care and detection of risk behaviours.

\section{Objectives - Materials and Methods: $\quad>$}

This model of attention identifies and integrates the different visions about the mental illness and the biopsychosocial functioning and cultural from the community and the medical team that look for a close up to the mental health team and populations far from the rural centers and beaten by the violence phenomenon, the displacement and migration. This model articulates the multiple actors of the diverse health system and the society.

\section{Results - Conclusions $>$}

The management mechanisms necessary to articulate the psychosocial and academic work toward scenes of violence and displacement, while an intersectorial dialogue is constructed to strengthen and ensure the execution of these projects.

Being able to identify the meaning of health care and mental illness in the indigenous and rural community, the way to offer a treatment and an approach from its conception and by the same means always preserving limits of respectfulness because of the previous knowledge about the community.

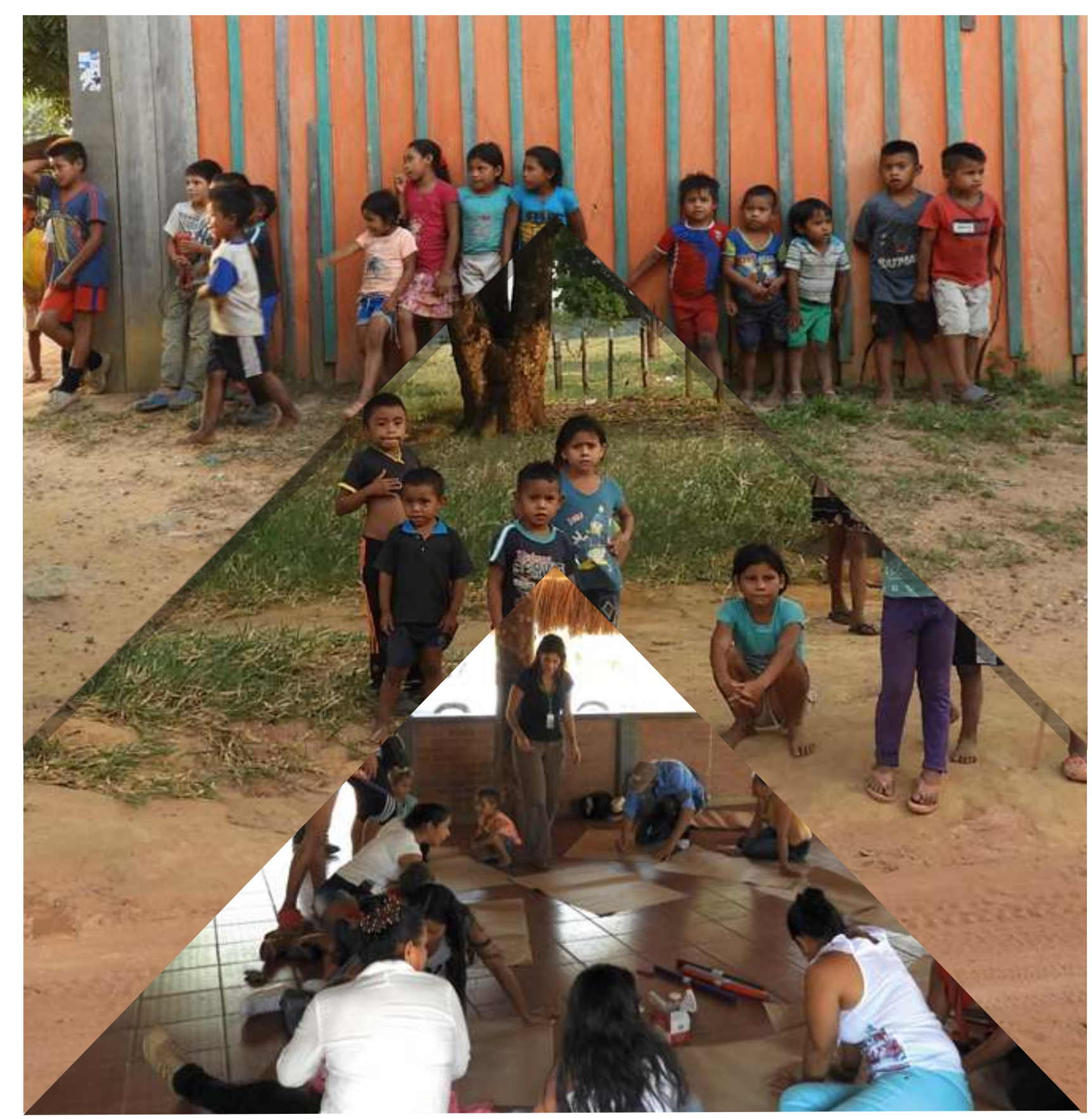

\section{Bibliography}

1) Análisis de Situación de Salud con el Modelo de los Determinantes Sociales de Salud. Dirección Local de Salud, Plan Territorial de Salud. Vigilancia en Salud Pública. Municipio Puerto Gaitán 2016.

2) Política pública indígena Gobernación del Meta.

3) Martínez, Marco Julián. “Segundo Informe: Indígenas de los Llanos del Casanare y Arauca: Sicuani. Wäpijiwi y Sáliba”. Ministerio de Cultura- ICANH. Bogotá. 2008 4) Sánchez, Enrique \& Raúl Arango. Los Pueblos Indígenas de Colombia en el Umbral del nuevo milenio. DNP - DDTS. Bogotá. 2004

5) Suárez, Carlos José. Ministerio de Cultura - ICANH. "Informe sobre la Integridad Cultural de los Pueblos Yukpa, Chimila, Wiwa, Sikuani y Saliba". Bogotá. 2008

6) Henao S, Quintero S, Echeverri J, Hernández J, Rivera E, López S. Políticas públicas vigentes de salud mental en Suramérica: un estado del arte. Rev. Fac. Nac. Salud Pública 2016; 34(2): 184-192. 